\title{
Bioactivity of Anacardium occidentale (L) and Allium sativum (L) Powders and Oils Extracts against Cowpea Bruchid, Callosobruchus maculatus (Fab.) [Coleoptera: Chrysomelidae]
}

\author{
K. D. Ileke (Corresponding author) \\ Department of Environmental Biology and Fisheries \\ Adekunle Ajasin University, PMB 001 \\ Akungba Akoko, Ondo State, Nigeria \\ Tel: 234-803-431-8706_E-mail: kayodeileke@yahoo.com \\ O. F. Olotuah \\ Department of Plant Science and Biotechnology \\ Adekunle Ajasin University, PMB 001 \\ Akungba Akoko, Ondo State, Nigeria
}

Received: October 10, 2011

Accepted: October 25, $2011 \quad$ Published: January 1, 2012

doi:10.5539/ijb.v4n1p96

URL: http://dx.doi.org/10.5539/ijb.v4n1p96

\begin{abstract}
The powders and oils extracts of Anacardium occidentale (L.) seeds and Allium sativum (L.) bulbs were tested as contact insecticides against the cowpea bruchid, Callosobruchus maculatus (Fab.) in cowpea seeds. The powders were incorporated at rates $1,2.5$ and $5 / 20 \mathrm{~g}$ of cowpea seeds and acetone extracts of the plants were also applied at $0.5,1$ and $1.5 \mathrm{ml}$ per $20 \mathrm{~g}$ of cowpea seeds to assess contact mortality of adult insect, oviposition, adult emergence and damage assessment. The results obtained showed that at 72 hours; $1,2.5$ and 5/20g of cowpea seeds evoked $63.3,80$ and $100 \%$ adult mortality of the cowpea bruchid while the corresponding results for $A$. sativum were $60.7,73.3$ and $100 \%$ mortality respectively. All concentration of acetone extracts that were used evoked $100 \%$ mortality of C. maculatus after 72 hours of post treatment. Complete protection of seeds and complete inhibition of adult emergence in both powders and extracts of A. occidentale and A. sativum were achieved. The results obtained from this research revealed that powders and extracts of $A$. occidentale seeds and A. sativum bulbs were effective in controlling cowpea bruchid, C. maculatus in stored cowpea seeds.
\end{abstract}

Keywords: Callosobruchus maculatus, Anacardium occidentale, Allium sativum, Bioactivity, Biopesticide, Cowpea seed, Weevil Perforation Index

\section{Introduction}

Cowpea, Vigna unguiculata occupy a prominent place in the nutrition of Nigerians because their edible seeds form cheap alternative source of dietary protein (Ofuya, 2001; Ofuya and Adedire , 2004; Adedire et al., 2011). Cowpea seeds are veritable source of minerals and vitamins such as calcium, thamine and riboflavin (Nelson, 1991). Cowpea have therefore been described as "poor man's meat".

The major problem facing grains storage in Nigeria and other Africa countries are several insect pests including weevils, beetles and moths, leading to loss in weight and seeds quality (Adedire, 2001; Udo, 2005; Akinkurolere et al., 2006; 2009; Adedire et al., 2011). Bruchid especially those belonging to the genus Callosobruchus can infest stored cowpea seeds (Ofuya and Bamigbola, 1991) and this insect pest has been recognized as a constraint to food security in African (Markham et al., 1994). Apart from contamination of food grains by dead insects, pupae and larval cocoons, their integument has been found to contain various carcinogenic compound such as ethyl, methyl and methoxy quinines which can not be denatured by boiling or baking (Zehrer, 1980; Adedire et al., 2011). 
The effective measures in food pest control is the use of synthetic insecticides, which are very expensive, unavailable at critical period and they are sometimes constitute health hazards to consumers (Adedire, 2001; Ofuya, 2001; Oni and Ileke, 2008; Ileke and Oni, 2011; Oni, 2011). This led to continuous research towards substitution of synthetic insecticides with plant products as a cheaper and eco-friendly safer means of controlling insect pest's infestation of stored cowpea seeds (Adedire et al., 2011). Attention is being given to the use of edible plants materials as grains protectant (Ivbijaro and Agbaje, 1986; Adedire and Lajide, 2003; Akinkurolere et al., 2009; Ileke and Oni, 2011) and the tropic is well endowed with these plant species some of which are also used for medicinal purpose (Adedire and Lajide, 2003; Ileke and Oni, 2011)

Garlic, Allium sativum, is a cosmopolitan plant. It is an herbaceous biennial plant, characterized by its penetrating fragrance. It is a seasoning for soups and sauces and its oil is a flavoring agent. Medically, the bulb is used for reviving convulsive patients, cure for hemorrhoids and diuretic in Nigeria (Dike and Mbah, 1992). The pesticidal activities of garlic as a repellent, antifeedant, bactericide, fungicide and nematicide have been reported (Graigne et al., 1985; Oparaeke and Dike, 1996). Cashew, Anacardium occidentale, fruit consists of a soft, shing, pear-shaped, swollen, juice basal portion commonly known as a 'cashew apple'. The apple is sweet when fully ripe. The seeds are inedible when raw and must be cooked or roasted to drive off the volatile oil before it is opened or shelled (Anon, 1958; Oparaeke and Bunmi, 2006). The medicinal value of these plants has long been known. Therefore, the plants were believed to be safer as biopesticides for stored food protection (Arannilewa et al., 2006; Oparaeke and Bunmi, 2006; Adedire et al., 2011). This led to the present research.

\section{Materials and Methods}

\subsection{Insect cultures}

Parent stock of Callosobruchus maculatus was obtained from established laboratory culture at Environmental Biology and Fisheries Laboratory, Adekunle Ajasin University, Akungba Akoko, Ondo State, Nigeria. This was reared on disinfested cowpea seeds collected from Seed Unit, Agricultural Development Programme, Ado Ekiti, Ekiti State, Nigeria. The seeds were cleaned of foreign matter and disinfested by keeping in freezer at $-5^{\circ} \mathrm{C}$ for 7 days. This is because all the life stages, particularly the eggs are very sensitive to cold (Koehler, 2003). The disinfested seeds were then air dried in the laboratory to prevent mouldiness (Adedire et al., 2011) before introduction of insects. They were placed in Kilner jars and covered with muslin cloth. The jars were placed in insect rearing cages at ambient temperature of $30 \pm 3^{\circ} \mathrm{C}$ and $70 \pm 5 \%$ relative humidity.

Cowpea, Vigna unguiculata seeds used for the experiment were also disinfested as described above before it was stored in plastic containers with tight lids disinfested by swabbing with $90 \%$ alcohol.

\subsection{Collection of plant materials}

The plants materials used in the present study were Anacardium occidentale and Allium sativum. Cashew nuts were sourced fresh from Ita Merin farm at Igbara-odo Ekiti, Ekiti State, Nigeria and bulbs of Garlic was purchase fresh at Oja Oba market, Igbara-odo Ekiti, Ekiti State, Nigeria. The nuts were sun dried for three days to allow for safe and easy cracking to remove the nuts without crushing them (Adedire et al., 2011). These plant materials were later dried in an open laboratory and ground into very fine powder using an electric blender (Supermaster ${ }^{\circledR}$, Model SMB 2977, Japan). The powders were further sieved to pass through $1 \mathrm{~mm}^{2}$ perforations (Ileke and Oni, 2011) before it was stored in separate plastic containers with tight lids and stored in a refrigerator at $4^{\circ} \mathrm{C}$ prior to use.

Acetone extracts of $A$. occidentale and A. sativum seeds and bulbs respectively were carried out using cold extraction method. About $250 \mathrm{~g}$ of $A$. occidentale and A. sativum powders were soaked separately in an extraction bottle containing $70 \%$ acetone. The mixture was stirred occasionally with a glass rod and extraction was terminated after 72 hours. Filtration was carried out using a double layer of Whatman No. 1 filter papers and acetone evaporated using a rotary evaporator at 30 to $40^{\circ} \mathrm{C}$ with rotary speed of 3 to $6 \mathrm{rpm}$ for 8 hours (Udo, 2011). The resulting extract was air dried in order to remove traces of solvent.

\subsection{Toxicity of plant powders}

Portions of 1, 2.5 and $5 \mathrm{~g}$ of each plant powders corresponding to $5,12.5$ and $25 \% \mathrm{w} / \mathrm{w}$ concentration (Fatope et $a l ., 1995)$ were weighed and each added to a $20 \mathrm{~g}$ of clean undamaged and uninfested cowpea seeds in $250 \mathrm{ml}$ plastic containers. The seeds in the controls contained no plant powders. The containers with their contents were gently shaken to ensure thorough admixture of the cowpea seeds and treatment powders. Ten pairs of a Teneral adults $C$. maculatus were introduced to each of the containers and covered. The insects were sexed based on the observation reported by Odeyemi and Daramola (2000). Three replicates of the treatments and untreated controls were laid out in Complete Randomized Design. The adult mortality was assessed after every 24 hours for 96 
hours. On day 5, all insects, both dead and alive were removed from each container and ovipositon were noted before returned the seeds to their respective containers. Adult emergence (F1) was then recorded at 6 weeks. The percentage adult emergence was calculated thus:

$$
\% \text { Adult emergence }=\frac{\text { No of adults emerged }}{\text { No of eggs laid }} \times \frac{100}{1}
$$

At day 42 , the cowpea seeds were re-weighed and the $\%$ loss in weight was determined and recorded. The percentage seed damaged were also evaluated as follows:

$$
\% \text { seed damage }=\frac{\text { Number of seeds damaged }}{\text { Total number of seeds }} \times \frac{100}{1}
$$

Weevil Perforation Index (WPI) of the weevil to cowpea seeds were calculated using the methods of Fatope et al., (1995); Adedire and Ajayi (1996) respectively. The weevil perforation is define as follows:

$$
\text { WPI }=\frac{\% \text { treated cowpea seeds perforated }}{\% \text { control cowpea seeds perforated }} \times \underline{100}
$$

\subsection{Toxicity of plants extracts}

The toxic effect of plants oils on adult $C$. maculatus was accomplished using $250 \mathrm{ml}$ plastic containers containing $20 \mathrm{~g}$ of cowpea seeds with concentration of $0.5,1$ and $2 \% \mathrm{w} / \mathrm{v}$ plant extracts in acetone. The oils were thoroughly mixed with the aid of a glass rod and agitated for 5-10 mins to ensure uniform coating. The containers were left open for 30 mins so as to allow traces of acetone to evaporate off. Ten copulating pairs of $C$. maculatus were introduced into the containers and mortality was observed daily for 4 days. Cowpea seeds that were solvent treated served as the control experiment (Arannilewa et al., 2006). Three replicates of the treatments and untreated controls were laid out in Complete Randomized Design. Adult insects were considered dead where no response was observed after probing them with forceps.

The effect of extracts on adult emergence was recorded after 42 days. At the end of 42 days, the extent of weight loss as a result of weevil development, damaged to seeds and weevil perforation index (WPI) were calculated as described under toxicity of plant powders.

\subsection{Statistical analysis}

Data were subjected to analysis of variance and where significant differences existed, treatment means were separated using the New Duncan's Multiple Range Test (Zar, 1984).

\section{Results}

\subsection{Toxicity of plants powders to Callosobruchus maculatus}

Table 1 compares the effectiveness of two plants powders on mortality of cowpea bruchid. All the plants powders at different concentration had above $60 \%$ mortality when compared with untreated which had no mortality after 72 hours of post treatment. Cashew seed powders evoked $63.3 \%, 80 \%$ and $100 \%$ mortality of adult bruchid at rates of $1 / 20 \mathrm{~g}, 2.5 / 20 \mathrm{~g}$ and $5 / 20 \mathrm{~g}$ of cowpea seeds after 72 hours of post treatment respectively. There was no significant different $(\mathrm{P}>0.05)$ in mortality of adult bruchid among the treatment with $A$. occidentale powder evoking $100 \%$ mortality irrespective of concentration after 96 hours of post treatment. In similar vein, A. sativum caused $60.7 \%, 73.3 \%$ and $100 \%$ mortality of $C$. maculatus at rates of $1 / 20 \mathrm{~g}, 2.5 / 20 \mathrm{~g}$ and $5 / 20 \mathrm{~g}$ of seeds at $72 \mathrm{hours}$ of post treatment. Garlic powder was able to produced $100 \%$ mortality of bruchid at rates of $2.5 / 20 \mathrm{~g}$ and $5 / 20 \mathrm{~g}$ of cowpea seeds apart from cowpea seeds treated at rate of $1 \mathrm{~g}$ that evoked $83.3 \%$ mortality of bruchid after 4 days of exposure.

\subsection{Effect of plants powders on oviposition and adult emergence of C. maculatus}

All the plants powders significantly reduced the number of eggs laid by C. maculatus (Table 2). The A. occidentale powders at all concentration completely prevented the emergence of adult $C$. maculatus when compared with the control that recorded 90 adult emergence. Seeds treated with A. sativum had no adult emergence apart from seeds treated at rate $1 \mathrm{~g}$ that recorded 15 adult emergence.

\subsection{Toxicity of plants Extracts to Callosobruchus maculatus}

Significant mortality of adult $C$. maculatus $(\mathrm{P}<0.05)$ were observed at all concentration of the extract after 48 hours of post treatment with $A$. occidentale at $1.5 \mathrm{ml}$ per $20 \mathrm{~g}$ of cowpea seeds evoking $100 \%$ adult mortality after 
24 hours of post treatment (Table 3). All extracts of the two plants at different concentrations were able to evoked $100 \%$ mortality of adult bruchid apart from the extract of $A$. sativum at $0.5 \mathrm{ml}$ per $20 \mathrm{~g}$ of cowpea seeds that produced $80 \%$ adult mortality of C. maculatus after 72 hours of post treatment.

\subsection{Effect of plants Extracts on oviposition and adult emergence of C. maculatus}

All the plant extracts significantly reduced the number of eggs laid by cowpea bruchid compared to untreated cowpea seeds that had 84 eggs (Table 4). The percentage adult emergence in the untreated was significantly different $(\mathrm{P}>0.05)$ from all the treated cowpea seeds that recorded no adult emergence. The extract completely inhibited the F1 development of $C$. maculatus.

\subsection{Damage assessment of cowpea seeds treated with plant powders and extracts}

Cowpea seeds treated with plants powders showed no significant different (P.0.05) in the reduction of damaged caused by C. maculatus (Table 5). However, the weevil perforation index (WPI) of 5.2 recorded on cowpea seeds treated with powder of $A$. sativum treated at rate $1 \mathrm{~g}$ was significantly different $(\mathrm{P}>0.05)$ from weevil perforation index of the untreated cowpea seeds. In similar vein in Table 6, there was neither seed damage nor weight loss recorded in the treated cowpea seeds at all concentration. The weevil perforation index (WPI) was zero for all the tested plants extracts compared to untreated cowpea seeds.

\section{Discussion}

Cashew, A. occidentale seed powder and oil completely killed adult C. maculatus on stored cowpea seeds. This insecticidal effect was in agreement with Dungum et al. (2005), Oparaeke and Bunmi (2006) and Adedire et al. (2011). The mode of action of this plant powder oil could be as a result of the powder and oil coating the treated cowpea seeds which prevented contact between the seeds and the bruchid resulting into starvation. They also blocked the spiracles which may lead to suffocation as suggested by (Hall and Harman, 1991; Adedire et al., 2011). The insecticidal activity of $A$. occidentale oil extract could be linked to the presence of anacardic acid and cardinal (Rehm and Espig, 1991). Others include quercetin and kaempferol glycosides (Oliver-Bever, 1986).

Garlic powder and oil may have been very toxic to C. maculatus as a result of the strong choky odours it produce which may disrupt normal respiratory activity of insect, thereby leading into asphyxiation and subsequent death (Adedire and Ajayi, 1996). This result agrees with the finding of Bhatnager-Thomas and Pal (1974) who reported the effectiveness of garlic oil against Musca dominica and Trogoderma granarium. Nasseh (1990) reported the insecticidal activities of A. sativum for the control of Epilachna verivestis. Arannilewa et al. (2006) reported $85 \%$ adult mortality of Sitophilus zeamais and 9 emerged adult maize weevil on treated maize grains with methanol extract of $A$. sativum.

The reduced oviposition and no adult emergence observed in all the treated seeds with oils extract could be as a result of high adult mortality of $C$. maculatus. The oil inhibits locomotion which affect mating activities an effect that had been reported by many authors (Okonkwo and Okoye, 1996; Adedire, 2002, Akinkurolere et al., 2006, Oni and Ileke, 2008; Adedire et al., 2011; Ileke and Oni, 2011). The few eggs that were laid are unable to stick to the surface of the seeds as a result of oil presence also prevents progeny production. The lower F1 adult bruchid in cowpea seeds treated with A. sativum powder at rate of $1 \mathrm{~g}$ may be due to concentration used. The ovicidal and larvicidal of the plants powders and oils may be due to the present of lipophlic compound (Richards, 1978). Don-Pedro (1990) reported that eggs mortality may be as a result of physical properties of the oils resulting into blockage of respiratory pores (spiracle) while the larvicidal properties of the plants oils could be as a result of both physical and chemical toxicity of oils (Ivbijaro, 1984).

The plants powders and oils completely protected the seeds from been damaged by C. maculatus. The protectant ability of these plants powders and oils were highly remarkable. This may be as a result of ovicidal and larvicidal properties of the tested plant that completely killed few eggs that were laid and also prevent the few once that hatched into larva from going into pupa stage.

\section{Conclusion}

The result obtained from this study confirmed that powders and oils of A. occidentale seed and A. sativum can be used as biopesticides against C. maculatus especially when weevil perforation index is taken into consideration.

\section{Acknowledgments}

The authors are grateful to the Technologists in the of Department of Chemistry and Industrial Chemistry, Adekunle Ajasin University, Akungba Akoko, Ondo State, Nigeria for their technical assistance during the extraction of cashew seeds and garlic bulbs. 


\section{References}

Adedire, C.O \& Ajayi, T.S. (1996). Assessment of the insecticidal properties of some plant extracts as grain protection against the maize weevil, Sitophilus zeamais. Nigerian Journal of Entomology, 13, 93-101.

Adedire, C.O \& Lajide, L. (2003). Ability of extracts of ten tropical plant species to protect maize grains against infestation by the maize weevil Sitophilus zeamais during storage. Nigerian Journal Experimental Biology, 4(2), 175-179.

Adedire, C.O. (2001). Biology, ecology and control of insect pests of stored grains. Ofuya T.I. and Lale, N.E.S. (Eds). Pest of Stored Cereals and Pulses in Nigeria. Dave Collins publications, Nigeria. Pp. 59-94.

Adedire, C.O. (2002). Use of nutmeg, Myristica fragrans (Houtt) powder and oil for the control of cowpea storage bruchid, Callosobruchus maculatus. Journal of Plant Diseases and Protection, 109. 193-199.

Adedire, C.O., Obembe, O. O., Akinkurolele, R. O. \& Oduleye, O. (2011). Response of Callosobruchus maculatus (Coleoptera: Chysomelidae: Bruchidae) to extracts of cashew kernels. Journal of Plant Diseases and Protection, 118(2), 75-79.

Akinkurolele, R. O., Adedire, C. O. \& Odeyemi, O. O. (2006). Laboratory evaluation of the toxic properties of forest anchomanes, Anhomanes difformis, against pulse beetle, Callosobruchus maculatus (Coleoptera: Bruchidae). Insect Science, 13, 25-29. http://dx.doi.org/10.1111/j.1744-7917.2006.00064.x

Akinkurolere, R. O., Boyer, S., Chen, H. \& Zhang, H. (2009). Parasitism and host location preference in Habrobracon hebetor (Hymenoptera: Braconidae): Role of refuge, choice and host instar. Journal Economics Entomology, 102(2), 610-615. http://dx.doi.org/10.1603/029.102.0219

Arannilewa S. T., Ekrakene, T. \& Akinneye, J. O. (2006). Laboratory evaluation of four medicinal plants as protection against the maize weevil, Sitophilus zeamais. African Journal of Biotechnology, 5(21), 2032-2036.

Bhatnager-Thomas, P. L. \& Pal, A. K. (1974). Studies on the insecticidal activity of garlic oil; differential toxic of the oil to Musca domestics and Trogoderma granarium. Journal of Food Science and Technology, 11(3), 101-113.

Dike, M. C. \& Mbah, O. I. (1992). Evaluation of the lemon grass products in the control of Callosobruchus maculatus on stored cowpea. Nigerian Journal of Crop Protection, 14, 88-91.

Don-Pedro, K. N. (1990). Insecticidal activity of fatty acid constituents of fixed vegetable oils against Callosobruchus chinensis on cowpea. Pesticide Science, 30, 295-305. http://dx.doi.org/10.1002/ps.2780300306

Fatope, M. O., Mann, A. \& Takeda, Y. (1995). Cowpea weevil bioassay: A simple prescreen for plants with grain protectant effects. International Journal of Pest Management, 41, 44-86.

Graingne, M; Ahmed, S, Mitchel, W. C. \& Hylin, J. N. (1985). Plant species reportedly possessing pest control properties and EWC/UH data base- Resource systems Institute, EWC. Honolulu, College of Tropical Agriculture and Human Resource, University of Hawaii.

Hall, J. S. \& Harman, G. E. (1990). Protection of stored legume seeds against attack by storage fungi and weevil: Mechanism of action of lipoided and oil seed treatment. Crop Protection, 10, 375-380. http://dx.doi.org/10.1016/S0261-2194(06)80027-X

Ileke, K. D. \& Oni, M. O. (2011). Toxicity of some plant powders to maize weevil, Sitophilus zeamais (Coleoptera: Curculionidae) on stored wheat grains. African Journal of Agricultural Research, 6(13), 3043-3048.

Ivbijaro, M. F. (1984). Groundnut oil as a protectant of maize from damage by maize weevil Sitophilus zeamais Protection Ecology, 6, 267-270.

Koehler, P. G. (2003). Biopesticides (Volume 2). Entomology and Nematology Dept, University of Florida, Gainesuilla 326pp.

Markham, R. H., Bosque-perez, N. A., Borgemeister, C. \& Meikle, W. G. (1994). Developing pest management strategies for maize weevil, Sitophilus zeamais and larger grain borer, Prostephanus truncatus, in the humid and sub-humid tropics. FAO Plant Protection Bulletin, 42(3), 97-116.

Mbailao, M., Nanadoum, M, Automne, B., Gabra, B \& Emmanuel, A. (2006). Effect of six common seed oils on survival, egg lying and development of the cowpea weevil, Callosobruchus maculatus. Journal of Biological Sciences, 6(2), 420-425. http://dx.doi.org/10.3923/jbs.2006.420.425 
Nasseh, M. O. (1990). Studies on insecticidal activities of Allium sativum for control of Epilachna verivestis (Coleoptera: Coccinelidae). Zurich Angewandte Entomologie, 92, 464-471. http://dx.doi.org/10.1111/j.1439-0418.1981.tb01697.x

Nelson, S. N. (1991). Digestibility of Legume Protein. Food Technology, 45, 112-114.

Ofuya, T. I \& Bamigbola, K. A. (1991). Damage Potential, growth and development of the seed beetle, Callosobruchus maculatus (Fab.) (Coleoptera: Bruchidae) on some tropical legumes. Tropical Agriculture, 68, 33-36.

Ofuya, T. I. \& Adedire, C. O. (2004). Sustainable protection of stored crops against insect depredation in the tropics 2(152-165). College Press and Publisher Ltd, Ibadan Nigeria.

Ofuya, T. I. (1992): Oviposition deterrence and ovicidal properties of some plant powders against C. maculatus in stored cowpea seeds. Journal of Agricultural Sciences, 115, 343-345. http://dx.doi.org/10.1017/S0021859600075766

Ofuya, T.I. (2001). Biology, Ecology and control of insect pests of stored Food legumes. In: pp 59-94. Ofuya T.I. and Lale, N.E.S. (eds) pest of stored cereals and pulses in Nigeria. Dave Collins publications, Nigeria. Pp 25-58.

Okonkwo, E. U. \& Okoye, W. I. (1996). The efficacy of four seed powders and the essential oils as protestants of cowpea and maize grains against infestation by Callosobruchus maculatus and Sitophilus zeamais Nigeria International Journal Pest Management, 42(3), 143-146. http://dx.doi.org/10.1080/09670879609371985

Oliver-Bever, B. (1986). Medicinal plants in tropical West Africa. Cambridge University Press, Cambridge, United Kingdom. http://dx.doi.org/10.1017/CBO9780511753114

Oni, M. O. (2011). Evaluation of seed and fruit powder of Capsicum annum and C. frutescens for control of Callosobruchus maculatus (Fab.) in stored cowpea and Sitophilus zeamais in stored maize. International Journal of Biology, 3(2), 185-188. http://dx.doi.org/10.5539/ijb.v3n2p185

Oni, M.O. \& Ileke, K. D. (2008). Fumigant toxicity of four botanical plant oils on survival, egg laying and progeny development of the dried yam beetle, Dinoderus porcellus (Coleoptera: Bostrichidae). Ibadan Journal of Agricultural Research, 4(2), 31-36.

Oparaeke, A. M. \& Bunmi, O. J. (2006). Insecticidal potential of cashew, Anacardium occidentale for control of the beetle, Callosobruchus subinnotatus on bambara groundnut. Archives of Phytopathology and Plant Protection, 39(4), 247-251. http://dx.doi.org/10.1080/03235400500094431

Oparaeke, A. M. \& Dike, M. C. (1996). Comparison of garlic and lemon grass products in the control of Callosobruchus maculatus on stored cowpea grains. Nigerian Journal of Entomology, 13, 73-80.

Rehm, S. \& Espig, G. (1991). The Cultivated Plants of the Tropics and Subtropics. Cultivation, Economic Value, Utilization. Verlag Josef Margraf Scientific Books, CTA, 522pp.

Richards, A. G. (1978). The chemistry of insect cuticle. In: Biochemistry of insects, Academic Press, New York, U. S. A. pp. 205-232.

Udo, I. O. (2005). Evaluation of the potential of some local spices as stored grain protectants against maize weevil Sitophilus zeamais. Journal of Applied Science and Environmental Management, 9(1), 165-168

Zar, J. H. (1984). Biostatatical Analysis, $2^{\text {nd }}$ ed, Prentice- Hall International, Englewood Cliffs, N. J.

Zehrer, W. (1980). Traditional methods of insect pest control in stored grain. In: Post harvest problems. Documentation of a OAU/GTZ Seminar. Lome, p. 45. 
Table 1. Effect of plants powders on percentage mortality of Callosobruchus maculatus adults

\begin{tabular}{|c|c|c|c|c|c|}
\hline \multirow{2}{*}{ Plant powder } & \multirow{2}{*}{$\mathrm{g} / 20 \mathrm{~g}$ cowpea } & \multicolumn{4}{|c|}{ Mean $\%$ mortality \pm S.E. at $24 \mathrm{~h}$ to $96 \mathrm{~h}$ Post treatment } \\
\hline & & 24 & 48 & 72 & 96 \\
\hline \multirow{3}{*}{ A. occidentale } & 1.0 & $20.0 \pm 0.0 \mathrm{~b}$ & $46.7 \pm 0.3 b$ & $63.3+0.0 \mathrm{~b}$ & $100.0+0.0 \mathrm{c}$ \\
\hline & 2.5 & $33.3 \pm 0.0 \mathrm{c}$ & $53.3 \pm 0.0 \mathrm{~b}$ & $80.0 \pm 0.0 \mathrm{c}$ & $100.0 \pm 0.0 \mathrm{c}$ \\
\hline & 5.0 & $53.3+0.0 \mathrm{~d}$ & $73.3+0.0 \mathrm{c}$ & $100.0+0.0 \mathrm{~d}$ & $100.0 \pm 0.0 \mathrm{c}$ \\
\hline \multirow{3}{*}{ A. sativum } & 1.0 & $13.3 \pm 0.0 \mathrm{~b}$ & $46.7 \pm 0.3 b$ & $60.0 \pm 0.0 \mathrm{~b}$ & $83.3 \pm 0.0 \mathrm{~b}$ \\
\hline & 2.5 & $30.0 \pm 0.0 \mathrm{c}$ & $50.0 \pm 0.0 \mathrm{~b}$ & $73.3 \pm 0.0 \mathrm{c}$ & $100.0 \pm 0.0 \mathrm{c}$ \\
\hline & 5.0 & $50.0 \pm 0.0 \mathrm{~d}$ & $70.0 \pm 0.0 \mathrm{c}$ & $100.0+0.0 \mathrm{~d}$ & $100.0 \pm 0.0 \mathrm{c}$ \\
\hline Control & 0.0 & $0.0 \pm 0.0 \mathrm{a}$ & $0.0 \pm 0.0 \mathrm{a}$ & $0.0 \pm 0.0 \mathrm{a}$ & $0.0 \pm 0.0 \mathrm{a}$ \\
\hline
\end{tabular}

Each value is a mean of \pm standard error of three replicates. Means within the same column followed by the same letter(s) are not significantly different at $(\mathrm{P}>0.05)$ from each other using New Duncan Multiple Range Test.

Table 2. Effect of Plants powders on oviposition and adult emergence of Callosobruchus maculatus

\begin{tabular}{|c|c|c|c|}
\hline Plant powders & $\mathrm{g} / 20 \mathrm{~g}$ cowpea & No of Eggs & \%Adults Emergence \\
\hline \multirow{3}{*}{ A. occidentale } & 1.0 & $10.0 \pm 0.0 \mathrm{a}$ & $0.0 \pm 0.0 \mathrm{a}$ \\
\cline { 2 - 4 } & 2.5 & $10.3 \pm 0.0 \mathrm{a}$ & $0.0 \pm 0.0 \mathrm{a}$ \\
\cline { 2 - 4 } & 5.0 & $10.0 \pm 0.0 \mathrm{a}$ & $0.0 \pm 0.0 \mathrm{a}$ \\
\hline \multirow{3}{*}{ A. sativum } & 1.0 & $26.7 \pm 0.3 \mathrm{~b}$ & $14.8 \pm 0.1 \mathrm{~b}$ \\
\cline { 2 - 4 } & 2.5 & $10.0 \pm 0.0 \mathrm{a}$ & $0.0 \pm 0.0 \mathrm{a}$ \\
\cline { 2 - 4 } & 5.0 & $10.3 \pm 0.0 \mathrm{a}$ & $0.0 \pm 0.0 \mathrm{a}$ \\
\hline Control & 0.0 & $86.7 \pm 0.3 \mathrm{c}$ & $89.7 \pm 0.3 \mathrm{c}$ \\
\hline
\end{tabular}

Each value is a mean of \pm standard error of three replicates. Means within the same column followed by the same letter(s) are not significantly different at $(\mathrm{P}>0.05)$ from each other using New Duncan Multiple Range Test.

Table 3. Effect of plants extract on percentage mortality of Callosobruchus maculatus adults

\begin{tabular}{|c|c|c|c|c|c|}
\hline \multirow{2}{*}{ Plant powder } & \multirow{2}{*}{ Conc. $\mathrm{ml} / 20 \mathrm{~g}$} & \multicolumn{4}{|c|}{ Mean \% mortality \pm S.E. at 24h to 96h Post treatment } \\
\cline { 2 - 6 } & & 24 & 48 & 72 & 96 \\
\hline \multirow{3}{*}{ A. occidentale } & 0.5 & $46.7 \pm 0.3 \mathrm{bc}$ & $76.7 \pm 0.3 \mathrm{bc}$ & $100.0 \pm 0.0 \mathrm{~b}$ & $100.0 \pm 0.0 \mathrm{~b}$ \\
\cline { 2 - 6 } & 1.0 & $60.0 \pm 0.0 \mathrm{~d}$ & $80.0 \pm 0.0 \mathrm{c}$ & $100.0 \pm 0.0 \mathrm{~b}$ & $100.0 \pm 0.0 \mathrm{~b}$ \\
\cline { 2 - 6 } & 1.5 & $100.0 \pm 0.0 \mathrm{e}$ & $100.0 \pm 0.0 \mathrm{~b}$ & $100.0 \pm 0.0 \mathrm{~b}$ & $100.0 \pm 0.0 \mathrm{~b}$ \\
\hline \multirow{3}{*}{ A. sativum } & 0.5 & $30.0 \pm 0.0 \mathrm{~b}$ & $66.7 \pm 0.3 \mathrm{~b}$ & $100.0 \pm 0.0 \mathrm{~b}$ & $100.0 \pm 0.0 \mathrm{~b}$ \\
\cline { 2 - 6 } & 1.0 & $53.3 \pm 0.0 \mathrm{c}$ & $70.0 \pm 0.0 \mathrm{bc}$ & $100.0 \pm 0.0 \mathrm{~b}$ & $100.0 \pm 0.0 \mathrm{~b}$ \\
\hline Control & 1.5 & $70.0 \pm 0.0 \mathrm{~d}$ & $100.0 \pm 0.0 \mathrm{~d}$ & $100.0 \pm 0.0 \mathrm{~b}$ & $100.0 \pm 0.0 \mathrm{~b}$ \\
\hline
\end{tabular}

Each value is a mean of \pm standard error of three replicates. Means within the same column followed by the same letter(s) are not significantly different at $(\mathrm{P}>0.05)$ from each other using New Duncan Multiple Range Test. 
Table 4. Effects of Plants extract on oviposition and adult emergence of Callosobruchus maculatus

\begin{tabular}{|c|c|c|c|}
\hline Plant powders & Concentration $\mathrm{ml} / 20 \mathrm{~g}$ & No of Eggs & \%Adults Emergence \\
\hline \multirow{3}{*}{ A. occidentale } & 0.5 & $10.3 \pm 0.0 \mathrm{a}$ & $0.0 \pm 0.0 \mathrm{a}$ \\
\cline { 2 - 4 } & 1.0 & $10.0 \pm 0.0 \mathrm{a}$ & $0.0 \pm 0.0 \mathrm{a}$ \\
\cline { 2 - 4 } & 1.5 & $10.0 \pm 0.0 \mathrm{a}$ & $0.0 \pm 0.0 \mathrm{a}$ \\
\hline \multirow{3}{*}{ A. sativum } & 0.5 & $20.0 \pm 0.0 \mathrm{a}$ & $0.0 \pm 0.0 \mathrm{a}$ \\
\cline { 2 - 4 } & 1.0 & $14.7 \pm 0.3 \mathrm{a}$ & $0.0 \pm 0.0 \mathrm{a}$ \\
\cline { 2 - 4 } & 1.5 & $10.3 \pm 0.0 \mathrm{a}$ & $0.0 \pm 0.0 \mathrm{a}$ \\
\hline Control & 0.0 & $83.3 \pm 0.0 \mathrm{~b}$ & $86.7 \pm 0.3 \mathrm{~b}$ \\
\hline
\end{tabular}

Each value is a mean of \pm standard error of three replicates. Means within the same column followed by the same letter(s) are not significantly different at $(\mathrm{P}>0.05)$ from each other using New Duncan Multiple Range Test.

Table 5. Protectantability of the plants powders on cowpea seeds

\begin{tabular}{|l|l|l|l|l|l|l|}
\hline $\begin{array}{l}\text { Plant part } \\
\text { powders }\end{array}$ & $\begin{array}{l}\mathrm{g} / 20 \mathrm{~g} \\
\text { cowpea }\end{array}$ & $\begin{array}{l}\text { Mean total no } \\
\text { of seeds }\end{array}$ & $\begin{array}{l}\text { Mean no } \\
\text { of } \\
\text { damaged } \\
\text { seeds }\end{array}$ & $\begin{array}{l}\text { Mean \% seed } \\
\text { damaged }\end{array}$ & $\%$ weight loss & $\begin{array}{l}\text { Weevil } \\
\text { Perforation } \\
\text { Index (WPI) }\end{array}$ \\
\hline \multirow{4}{*}{ A. occidentale } & 1.0 & 93.3 & $0.0 \pm 0.0 \mathrm{a}$ & $0.0 \pm 0.0 \mathrm{a}$ & $0.0 \pm 0.0 \mathrm{a}$ & $0.0 \pm 0.0 \mathrm{a}$ \\
\cline { 2 - 7 } & 2.5 & 93.3 & $0.0 \pm 0.0 \mathrm{a}$ & $0.0 \pm 0.0 \mathrm{a}$ & $0.0 \pm 0.0 \mathrm{a}$ & $0.0 \pm 0.0 \mathrm{a}$ \\
\cline { 2 - 7 } & 5.0 & 94.7 & $0.0 \pm 0.0 \mathrm{a}$ & $0.0 \pm 0.0 \mathrm{a}$ & $0.0 \pm 0.0 \mathrm{a}$ & $0.0 \pm 0.0 \mathrm{a}$ \\
\hline \multirow{3}{*}{ A Sativum } & 1.0 & 94.3 & $4.0 \pm 0.0 \mathrm{a}$ & $4.2 \pm 0.4 \mathrm{a}$ & $0.7 \pm 0.3 \mathrm{a}$ & $5.2 \pm 0.1 \mathrm{a}$ \\
\cline { 2 - 7 } & 2.5 & 94.7 & $0.0 \pm 0.0 \mathrm{a}$ & $0.0 \pm 0.0 \mathrm{a}$ & $0.0 \pm 0.0 \mathrm{a}$ & $0.0 \pm 0.0 \mathrm{a}$ \\
\cline { 2 - 7 } & 5.0 & 93.3 & $0.0 \pm 0.0 \mathrm{a}$ & $0.0 \pm 0.0 \mathrm{a}$ & $0.0 \pm 0.0 \mathrm{a}$ & $0.0 \pm 0.0 \mathrm{a}$ \\
\hline Control & 0.0 & 94.3 & $76.7 \pm 0.3 \mathrm{~b}$ & $81.9 \pm 0.2 \mathrm{~b}$ & $84.7 \pm 0.3 \mathrm{~b}$ & $50.0 \pm 0.0 \mathrm{~b}$ \\
\hline
\end{tabular}

Each value is a mean of \pm standard error of three replicates. Means within the same column followed by the same letter(s) are not significantly different at $(\mathrm{P}>0.05)$ from each other using New Duncan Multiple Range Test.

*Weevil Perforation Index (WPI). Value lower than 50 is an index of positive protectant effect while WPI greater than 50 is an index of negative protectantability.

Table 6. Protectantability of the plants extracts on cowpea seeds

\begin{tabular}{|l|l|l|l|l|l|l|}
\hline $\begin{array}{l}\text { Plant part } \\
\text { powders }\end{array}$ & $\begin{array}{l}\text { Conc. } \\
\mathrm{ml} / 20 \mathrm{~g}\end{array}$ & $\begin{array}{l}\text { Mean total } \\
\text { no of seeds }\end{array}$ & $\begin{array}{l}\text { Mean no } \\
\text { of } \\
\text { damaged } \\
\text { seeds }\end{array}$ & $\begin{array}{l}\text { Mean \% seed } \\
\text { damaged }\end{array}$ & $\%$ weight loss & $\begin{array}{l}\text { Weevil } \\
\text { Perforation } \\
\text { Index (WPI) }\end{array}$ \\
\hline A.occidentale & 0.5 & 94.3 & $0.0 \pm 0.0 \mathrm{a}$ & $0.0 \pm 0.0 \mathrm{a}$ & $0.0 \pm 0.0 \mathrm{a}$ & $0.0 \pm 0.0 \mathrm{a}$ \\
\cline { 2 - 7 } & 1.0 & 94.7 & $0.0 \pm 0.0 \mathrm{a}$ & $0.0 \pm 0.0 \mathrm{a}$ & $0.0 \pm 0.0 \mathrm{a}$ & $0.0 \pm 0.0 \mathrm{a}$ \\
\cline { 2 - 7 } & 1.5 & 94.3 & $0.0 \pm 0.0 \mathrm{a}$ & $0.0 \pm 0.0 \mathrm{a}$ & $0.0 \pm 0.0 \mathrm{a}$ & $0.0 \pm 0.0 \mathrm{a}$ \\
\hline \multirow{3}{*}{ A. Sativum } & 0.5 & 94.3 & $0.0 \pm 0.0 \mathrm{a}$ & $0.0 \pm 0.0 \mathrm{a}$ & $0.0 \pm 0.0 \mathrm{a}$ & $0.0 \pm 0.0 \mathrm{a}$ \\
\cline { 2 - 7 } & 1.0 & 93.3 & $0.0 \pm 0.0 \mathrm{a}$ & $0.0 \pm 0.0 \mathrm{a}$ & $0.0 \pm 0.0 \mathrm{a}$ & $0.0 \pm 0.0 \mathrm{a}$ \\
\cline { 2 - 7 } & 1.5 & 93.7 & $0.0 \pm 0.0 \mathrm{a}$ & $0.0 \pm 0.0 \mathrm{a}$ & $0.0 \pm 0.0 \mathrm{a}$ & $0.0 \pm 0.0 \mathrm{a}$ \\
\hline Control & 0.0 & 93.7 & $72.3 \pm 0.0 \mathrm{~b}$ & $76.6 \pm 0.4 \mathrm{~b}$ & $82.7 \pm 0.3 \mathrm{~b}$ & $50.0 \pm 0.0 \mathrm{~b}$ \\
\hline
\end{tabular}

Each value is a mean of + standard error of three replicates. Means within the same column followed by the same letter(s) are not significantly different at $(\mathrm{P}>0.05)$ from each other using New Duncan Multiple Range Test.

*Weevil Perforation Index (WPI). Value lower than 50 is an index of positive protectant effect while WPI greater than 50 is an index of negative protectantability. 